University of Wollongong

Research Online

Faculty of Science, Medicine and Health -

Papers: part A

Faculty of Science, Medicine and Health

$1-1-2014$

\title{
The use of immobilised metal affinity chromatography (IMAC) to compare expression of copper-binding proteins in control and copper-exposed marine microalgae
}

\author{
Cassandra L. Smith \\ University of Wollongong, cs713@uowmail.edu.au \\ Jenny L. Stauber \\ CSIRO, jenny.stauber@csiro.au \\ Mark R. Wilson \\ University of Wollongong, mrw@uow.edu.au \\ Dianne F. Jolley \\ University of Wollongong, djolley@uow.edu.au
}

Follow this and additional works at: https://ro.uow.edu.au/smhpapers

Part of the Medicine and Health Sciences Commons, and the Social and Behavioral Sciences

\section{Commons}

\section{Recommended Citation}

Smith, Cassandra L.; Stauber, Jenny L.; Wilson, Mark R.; and Jolley, Dianne F., "The use of immobilised metal affinity chromatography (IMAC) to compare expression of copper-binding proteins in control and copper-exposed marine microalgae" (2014). Faculty of Science, Medicine and Health - Papers: part A. 1414.

https://ro.uow.edu.au/smhpapers/1414

Research Online is the open access institutional repository for the University of Wollongong. For further information contact the UOW Library: research-pubs@uow.edu.au 


\title{
The use of immobilised metal affinity chromatography (IMAC) to compare expression of copper-binding proteins in control and copper-exposed marine microalgae
}

\begin{abstract}
Toxicity of metals to aquatic organisms is dependent on both external factors, such as exposure concentration and water quality parameters, and intracellular processes including specific metal-binding sites and detoxification. Current models used to predict copper toxicity in microalgae do not adequately consider these intracellular processes. This study compared the copper-binding proteins from four species of marine microalgae, Dunaliella tertiolecta, Tetraselmis sp., Phaedactylum tricornutum and Ceratoneis closterium, in controls (no added copper) and following a 72-h exposure to copper (sufficient to inhibit growth by approximately $50 \%$ ). Cells were lysed by sonication, which was optimised to obtain 54-94\% cell rupture for the different algae. Cell lysates were processed by immobilised metal affinity chromatography (IMAC) using Cu2+ as the bound metal (i.e. Cu-IMAC). Bound proteins were subsequently analysed by SDS-PAGE, comparing proteins recovered from algae that were exposed to copper versus untreated control cells. Individual proteins for which copper exposure resulted in changes to proteins present were excised from gels and further analysed by nano LC ESI-MS/MS; proteins were identified using the Mascot database. Proteins identified in this way included heat-shock proteins, rubisco, $\alpha$ - and $\beta$-tubulins and ATP synthase ( $\beta$ subunit). The results established that Cu-IMAC is a useful approach to identify proteins involved in copper binding in algae. This study identified several proteins that may play an active role in responses to copper toxicity in marine microalgae.
\end{abstract}

\section{Keywords}

proteins, binding, copper, microalgae, expression, marine, compare, imac, chromatography, affinity, metal, immobilised, exposed, control, CMMB

\section{Disciplines}

Medicine and Health Sciences | Social and Behavioral Sciences

\section{Publication Details}

Smith, C. L., Stauber, J. L., Wilson, M. R. \& Jolley, D. F. (2014). The use of immobilised metal affinity chromatography (IMAC) to compare expression of copper-binding proteins in control and copper-exposed marine microalgae. Analytical and Bioanalytical Chemistry, 406 (1), 305-315. 
The use of immobilised metal affinity chromatography (IMAC) to compare expression of copper-binding proteins in control and copper exposed marine microalgae

Cassandra L. Smith ${ }^{\mathrm{a}, \mathrm{c}^{*}}$, Jennifer L. Stauber ${ }^{\mathrm{b}}$, Mark R. Wilson ${ }^{\mathrm{c}}$ and Dianne F. Jolley ${ }^{\mathrm{a}^{*}}$

\begin{abstract}
Affiliations
${ }^{a}$ School of Chemistry, University of Wollongong, NSW, 2522, Australia

${ }^{\mathrm{b}}$ CSIRO Land and Water, Locked Bag 2007, Kirrawee NSW 2232 Australia

${ }^{c}$ School of Biological Sciences, Illawarra Health and Medical Research Institute, University of Wollongong, NSW, 2522, Australia
\end{abstract}

\title{
Corresponding authors:
}

* C.L.Smith email: cs713@uowmail.edu.au *D.F. Jolley email: djolley@uow.edu.au 


\begin{abstract}
:
Toxicity of metals to aquatic organisms is dependent on both external factors, such as exposure concentration and water quality parameters, and intracellular processes including specific metal-binding sites and detoxification. Current models used to predict copper toxicity in microalgae do not adequately consider these intracellular processes. This study compared the copper-binding proteins from four species of marine microalgae, Dunaliella tertiolecta, Tetraselmis sp., Phaedactylum tricornutum and Ceratoneis closterium, in controls (no added copper) and following a 72-h exposure to copper (sufficient to inhibit growth by approximately $50 \%$ ). Cells were lysed by sonication, which was optimised to obtain 54 $94 \%$ cell rupture for the different algae. Cell lysates were processed by immobilised metal affinity chromatography (IMAC) using $\mathrm{Cu}^{2+}$ as the bound metal (i.e. Cu-IMAC). Bound proteins were subsequently analysed by SDS-PAGE, comparing proteins recovered from algae that were exposed to copper versus untreated control cells. Individual proteins for which copper exposure resulted in changes to proteins present were excised from gels and further analysed by nano LC ESI-MS/MS; proteins were identified using the Mascot database. Proteins identified in this way included heat-shock proteins, rubisco, $\alpha-$ and $\beta$ tubulins and ATP synthase ( $\beta$ subunit). The results established that $\mathrm{Cu}-\mathrm{IMAC}$ is a useful approach to identify proteins involved in copper binding in algae. This study identified several proteins that may play an active role in responses to copper toxicity in marine microalgae.
\end{abstract}

Keywords: Intracellular copper, Metalloprotein, Algae, 72-h bioassay, Sonication, SDSPAGE 


\section{Introduction:}

Copper is an essential trace nutrient that is an important component of many proteins and enzymes, however, even micronutrients become toxic at elevated concentrations [1]. Over the last century, the increasing use of copper in industrial activities (e.g. antifouling paints, algicide, fertilizer and pesticides [2]) and its presence in mining by-products, have seen an increase in the amount of copper being released into the aquatic environment [3].

Marine microalgae (in combination with other phytoplankton) are responsible for almost $50 \%$ of the planet's photosynthesis ( $\mathrm{CO}_{2}$ fixation), as well as a number of other critical processes, such as nitrogen fixation and phosphorus metabolism [4]. Microalgae are among the most sensitive species to copper [5]. It is, therefore, important to understand how and why copper affects marine microalgae, with subsequent direct and indirect effects on higher trophic levels.

At present, metal toxicity is generally predicted by models including the gill-surface interaction model (GSIM) [6] in fish, the free ion activity model (FIAM) [7,8] and the biotic ligand model (BLM) $[9,10]$. These models are based on a limited understanding of the mechanisms of metal toxicity. For example, the BLM assumes that the metal-ligand interaction does not alter the biotic ligand itself (in this case, the algal cell membrane) and does not provide any insight into the nature of the ligand. Thus, such models might not always accurately predict metal toxicity in different environments. Therefore, there is a need to identify the intracellular ligands with which metals interact in aquatic organisms to better understand the mechanisms of metal toxicity and to improve the prediction of toxicity. In the cell cytosol, copper is quickly bound by chaperones and transporter proteins with an affinity for copper [11]; like other essential metals, copper is tightly regulated within the cell and is actively transported to organelles where it plays a role in cellular function (e.g. it is an important co-factor in many enzymes, including the antioxidant enzyme, superoxide dismutase [12]). Alternatively, the copper can be sequestered in granules [11,13]. Adams et al. (unpublished) showed using synchrotron data that the location of copper in an algal cell is highly correlated with that of sulfur and phosphorus. Sulfur becomes incorporated into proteins within the amino acids cysteine and methionine. Non-protein sources of sulfur include glutathione (which constitutes the highest non-protein thiol within a cell) and phytochelatins [14]. Intracellular metals may be accumulated in specific organelles within the cell, e.g. subcellular fractionation of algal cells showed that cadmium was predominately in the organelle and the heat stable protein fractions [15]. This heat stable protein fraction contains the plant defence ligands, phytochelatins, which are known to bind metals and sequester them into a less bioavailable form [13]. The fact that copper enters the cytosol first, prior to being bound by ligands and redistribution in the cell, suggests that it is appropriate to target copper-ligand binding in the cytoplasm. The aim of this study therefore was to separate and where possible identify proteins to which copper binds in algal cells.

Immobilised metal affinity chromatography (IMAC) as a technique for purification of biomolecules was first presented by Porath et al. in 1975 [16]. They proposed that the affinity of proteins for metals could be used as a purification technique. The IMAC column retains 
proteins based on the interactions with the metal ions on the surface with a high specificity, allowing quick easy purification of even complex biological samples [17].

Copper (II) under the HSAB theory (hard soft acid base theory) is defined as a borderline acid $[18,19]$ meaning that it can form strong bonds to soft bases such as sulfur as well as harder ligands such as aromatic nitrogens, other nitrogens and oxygen. $\mathrm{Cu}$ (II) has shown a preference for $\mathrm{N}$ and $\mathrm{O}$ binding partners [20], amongst the amino acids, histidine in particular is a major binding partner [20,21]. The binding of proteins to $\mathrm{Cu}$-charged IMAC columns is therefore dominated by histidine residues. There exists a positive correlation between the amount of accessible histidines and the strength of binding. Typically one histidine is enough for weak binding to an IDA-Cu(II) complex (iminodiacetic acid, the stationary phase used in the IMAC columns in this study) [21].

IMAC can detect copper induced conformational changes in the proteins as their ability to bind to the column may change [22]. IMAC can be used to determine changes in metal-binding proteins and concentrations as a result of metal exposure. Metal-binding proteins may be altered when an over-abundance of metal is available in the cell, arising from exposure to elevated environmental metal concentrations.

IMAC (in particular $\mathrm{Cu}-\mathrm{IMAC}$ ) has been applied in a variety of applications including: isolating copper complexing ligands from natural waters [23-25] and identifying copper-binding ligands produced by various organisms including: marine bacteria [23,25], human hepatocytes [26], plants [27,28] and a marine cyanobacterium [29]. These studies have used IMAC to examine a variety of proteins from small peptides $(<2 \mathrm{kDa})[28,27,24]$ to larger proteins (up to $\sim 50 \mathrm{kDa}$ ) [25,29]. Barnett et al. [29] investigated metal-binding proteins from a marine cyanobacterium (Synechococcus sp.) using different metal-IMAC columns $(\mathrm{Ni}, \mathrm{Fe}$, and $\mathrm{Co}$ ) and found that while metal-binding proteins varied for each metal one oxidative stress protein, rubrerythrin was common to all.

In the current study, Cu-IMAC and SDS PAGE (sodium dodecyl sulphate polyacrylamide gel electrophoresis) were used to identify differences in the concentrations of copper-binding proteins recovered from lysates prepared from each of four species of marine microalgae, exposed for $72 \mathrm{~h}$ to either no copper or to their respective $\mathrm{IC}_{50}$ copper concentrations. The four species (and their respective 72-h $\mathrm{IC}_{50}$ copper concentrations) were: Dunaliella tertiolecta (Butcher) $(530 \mu \mathrm{g} \mathrm{Cu} / \mathrm{L})$, Tetraselmis sp. $(50 \mu \mathrm{g} \mathrm{Cu} / \mathrm{L})$, Ceratoneis closterium Enrenb. (Ehrenberg, 1839b:157) (formerly known as Cylindrotheca closterium and Nitzschia closterium) $(18 \mu \mathrm{g} \mathrm{Cu} / \mathrm{L})$ and Phaeodactylum tricornutum Bohlin $(8 \mu \mathrm{g} \mathrm{Cu} / \mathrm{L})[30,5]$. A working hypothesis was that algae that were more sensitive to copper would exhibit greater changes in expression levels of the copper binding proteins after a 72-h copper exposure than the less sensitive algae. 


\section{Experimental Methods}

\section{Algal culture and sample preparation}

Axenic algal cultures were originally obtained from the CSIRO Collection of Living Microalgae, Marine and Atmospheric Research (Hobart, Australia). Algae were maintained in autoclaved $\mathrm{f}_{2}$ media (half strength $\mathrm{f}$ media), except for $C$. closterium which was cultured in full strength $\mathrm{f}$ media [31]. Algae were kept at $21^{\circ} \mathrm{C}$, on $12: 12$ hour light:dark cycle at $110 \mu \mathrm{mol}$ photons. $\mathrm{m}^{-2} . \mathrm{s}^{-1}$ in a controlled environment incubation chamber (Labec, Australia). Algae were transferred into fresh media weekly. Culture flasks were agitated and randomly rotated within the incubator to promote gas exchange and to allow consistent light exposure. Copper exposure bioassays were conducted in silanised glassware to minimise copper losses to the glass walls of the flasks. Test media consisted of filtered sterilised seawater $(0.2 \mu \mathrm{m}$ PES (polyethersulfone) membrane, bottle top filters, Sartorius, Australia) supplemented with $15 \mathrm{mg} \mathrm{NO}{ }_{3}^{-} \cdot 1^{-1}$ and $1.5 \mathrm{mg} \mathrm{PO}{ }_{4}^{3-} \cdot 1^{-1}$ (added as $\mathrm{NaNO}_{3}$ and $\mathrm{NaH}_{2} \mathrm{PO}_{4}$, respectively). Copper was added as copper sulfate to each flask (except controls) to achieve the respective $\mathrm{IC}_{50}$ concentrations [5].

The density of algal cultures was determined by flow cytometry (LSR II, Becton Dickinson, Australia) using TruCount ${ }^{\mathrm{TM}}$ (BD Biosciences) beads as an internal reference standard. Algal cell chlorophyll a autofluorescence was measured by exciting at $488 \mathrm{~nm}$ and capturing the emission passing through a 685 long-pass barrier filter followed by a 695/40 band-pass filter. Data was acquired using FACSDiva software (V4.0, Becton Dickinson, Australia) and cell densities calculated as per Franklin et al. [32]. All samples were mixed by vortexing immediately prior to analysis to minimise algal settling and clumping.

\section{Method optimisation}

Several stages of the method needed to be optimised for application to marine algal cells. To liberate the proteins from the cells, cells were lysed by sonication. Sonication has been shown to be highly efficient at phytoplankton cell breakage [15,29]; it produces less metal contamination than other procedures such as freeze grinding and bead beating [29], and it avoids the addition of other chemicals such as enzymes and detergents that could also contaminate the sample. The main disadvantage of sonication is that the temperature of the sample may increase resulting in denaturation of some heat sensitive proteins. Thus, the optimal sonication parameters that allowed maximum cell disruption whilst avoiding heating and minimising detectable organelle disruption, were determined for each species.

After 72-h growth, 5-10 × $10^{8}$ cells were concentrated by centrifugation (1000 x g, $\left.5 \mathrm{~min}\right)$ and resuspended in $9 \mathrm{ml}$ of $20 \mathrm{mM}$ tris(hydroxymethyl)aminomethane- $\mathrm{HCl}$ salt (Tris) buffer ( $\mathrm{pH}$ 7.5) containing a protease inhibitor (Complete ${ }^{\mathrm{TM}}$ EDTA free protease inhibitor cocktail tablets, Roche, Germany) [29]. Sample tubes (3 x $3 \mathrm{ml}$ aliquots) were suspended in ice and treated with a $400 \mathrm{~W}$ digital sonifer (Branson) at amplitude $10 \%$ with a pulse cycle of $0.5 \mathrm{~s}$ ON and $1.0 \mathrm{~s}$ OFF for $5 \times 30 \mathrm{~s}$ (Tetraselmis sp.) or 2 × $30 \mathrm{~s}$ (P. tricornutum, D. tertiolecta and C. closterium). A pause of 5 minutes between sonication treatments prevented the samples 
from overheating. Tetraselmis sp. proved to be particularly resistant to sonication, and required a 45 min osmotic treatment with ultra-pure water prior to sonication to achieve satisfactory cell lysis. These parameters achieved cell lysis of $54 \pm 8 \%, 80 \pm 10 \%, 85 \pm 10 \%$ and $94 \pm 2 \%$ for Tetraselmis sp., P. tricornutum, C. closterium and D. tertiolecta, respectively. Cell damage was assessed by monitoring citrate synthase activity (normally contained in the mitochondrial matrix) before and after lysis [33,34]. After sonication cell lysates were recentrifuged at $4{ }^{\circ} \mathrm{C}(12000 \mathrm{x} \mathrm{g}, 5 \mathrm{~min})$. The supernatant was filtered $(0.45 \mu \mathrm{m}$, surfactant-free cellulose acetate membrane, Sartorius) prior to isolation of the copper-binding proteins and stored at $4{ }^{\circ} \mathrm{C}$ until analysis (for up to $2 \mathrm{~h}$ ).

\section{Optimisation of IMAC}

Fast protein liquid chromatography (FPLC, Akta Explorer) and HiTrap@ Chelating columns (1 or $5 \mathrm{ml} \mathrm{GE} \mathrm{Healthcare)} \mathrm{charged} \mathrm{with} \mathrm{Cu}^{2+}$ (as copper sulfate) were used to isolate copper-binding proteins from the samples. Columns were washed with at least five column volumes of $20 \mathrm{mM}$ Tris buffer ( $\mathrm{pH} 7.5,0.2 \mu \mathrm{m}$ filtered, $\mathrm{pH}$ adjusted with $\mathrm{KOH}$ ). The algal lysate (coloured) was loaded using a syringe and washed with a minimum five column volumes of the Tris buffer until the eluate was clear. Bound proteins were then eluted with three to five column volumes of the elution buffer $(200 \mathrm{mM}$ imidazole in $20 \mathrm{mM}$ Tris, $\mathrm{pH} 7.5$ adjusted using $\mathrm{HNO}_{3}$ ). The fraction containing the eluted proteins was collected and stored on ice for a maximum of $2 \mathrm{~h}$ prior to dialysis and electrophoresis. Although degradation of proteins cannot be discounted a number of steps were implemented to reduce degradation as much as possible: proteins were kept on ice; the procedure prior to IMAC separation was performed as rapidly as possible and the protease inhibitor was added prior to sonication.

Initial SDS-PAGE analysis of IMAC eluted proteins produced an unresolved smear with no distinct protein bands discernible necessitating further sample clean-up. An additional step was included in which membrane-bound proteins were removed by washing the IMAC column with detergent after the algal cell lysate had been loaded onto the column. Triton X100 was passed through the column, and the column was subsequently washed with twenty column volumes of loading buffer $(20 \mathrm{mM}$ Tris $\mathrm{pH} 7.5)$. The remaining bound proteins were eluted from the column using the elution buffer.

The imidazole was subsequently removed by dialysis to allow quick estimation of the protein content via an absorbance measurement at $280 \mathrm{~nm}$ using an arbitrary extinction coefficient $\left(\varepsilon^{0.1 \%}(280)=1.0\right)$. The sample was placed in $3.5 \mathrm{kDa}$ molecular weight cutoff (MWCO) dialysis tubing (Snakeskin ${ }^{\circledR}$ pleated dialysis tubing, Thermo scientific) and left in 11 of $20 \mathrm{mM}$ Tris buffer $\mathrm{pH} 7.5$ with stirring at $4{ }^{\circ} \mathrm{C}$ in the dark for approximately $48 \mathrm{~h}$, with a buffer change after $24 \mathrm{~h}$. If required, samples were concentrated (at $4{ }^{\circ} \mathrm{C}$ ) using small ultrafiltration devices with a 5-kDa MWCO (Vivaspin500, GE Life Sciences) and the protein concentration estimated as above.

The cell density required for $\mathrm{Cu}-\mathrm{IMAC}$ was also optimised. Unconcentrated eluted protein typically yielded $<0.2 \mathrm{mg}$ protein/ $\mathrm{ml}$ (estimated by A280 $\mathrm{nm}$ in a quartz micro-cuvette) from 5 to $10 \times 10^{8}$ cells and was concentrated to $\geq 3 \mathrm{mg}$ protein $/ \mathrm{ml}$ to facilitate subsequent analysis 
by SDS-PAGE. The two smaller brown pennate diatoms (C. closterium and P. tricornutum, cell volume $\left.50-70 \mu \mathrm{m}^{3}[1,5]\right)$ required much higher cell numbers $\left(\sim 1 \times 10^{9}\right.$ cells $)$ to yield a similar amount of copper binding protein as the larger green microalgae $\left(\sim 5 \times 10^{8}\right.$ cells $) D$. tertiolecta and Tetraselmis sp. (cell volume $300 \pm 100 \mu \mathrm{m}^{3}[1,5]$ ). This is not suprising given the disparity in cell sizes, as the green algae have more than three times the cell volume of the diatoms.

Proteins extracted from both the control and copper-exposed algae were not retained by the uncharged IMAC column (data not shown). This demonstrated that the proteins bound specifically to the immobilised copper and not to the support matrix of the column itself.

\section{1-Dimensional SDS-PAGE}

Concentrated proteins were separated using 1D SDS-PAGE (10\% SDS under reducing conditions) and visualised with Coomassie brilliant blue R-250 stain. All algal samples were prepared in duplicate; each biological replicate was run on multiple gels $(\underline{n} \geq 2)$ to ensure reproducibility. Gel bands of interest were excised and destained with a solution of $50 \%$ acetonitrile and $50 \mathrm{mM}$ ammonium bicarbonate prior to mass spectrometry analysis. Protein bands on the stained SDS-PAGE gels were optically scanned (Gel Logic 2200 Pro, Carestream Molecular Imaging software) and the relative intensity of each band estimated using the same software. All samples loaded onto the SDS-PAGE gels contained equal quantities of protein (typically 20-30 $\mu \mathrm{g}$ ).

\section{ESI qTOF MS Analysis (Electrospray ionisation quadrupole time-of-flight mass spectrometry)}

Excised gel bands were dried and then digested overnight with trypsin (150 ng) in $30 \mu \mathrm{lof}$ $25 \mathrm{mM}$ ammonium bicarbonate (pH 8). Samples were centrifuged (14,100 x g, $3 \mathrm{~min}$ ) and supernatants were diluted to $40 \mu \mathrm{l}$ in Electrospray Ionisation (ESI) loading buffer (2:97.9:0.1 acetonitrile:water:formic acid), injected onto a peptide trap (Michrome peptide Captrap) for pre-concentration and desalted with $0.1 \%$ formic acid, $2 \%$ acetonitrile $\left(\mathrm{CH}_{3} \mathrm{CN}\right)$ at $8 \mu \mathrm{l} / \mathrm{min}$. The peptide trap was then switched into line with the analytical column (SGE ProteCol C18, $300 \mathrm{~A}, 3 \mu \mathrm{m}, 150 \mu \mathrm{m} \times 10 \mathrm{~cm}$ and Exigent TEMPO nanoflow). Peptides were eluted from the column using a linear solvent gradient, with steps, from water:acetonitrile 100:0 to 10:90 $(+0.1 \%$ formic acid) at $500 \mathrm{nl} / \mathrm{min}$ over an $80 \mathrm{~min}$ period. The LC eluent was subject to positive ion nanoflow electrospray mass spectrometry (MS) analysis on a Q Star Elite (AB Sciex) which was operated in an information dependant acquisition mode (IDA). In IDA mode a TOF-MS (time of flight-mass spectrometry) survey scan was acquired $(\mathrm{m} / \mathrm{z} 400$ $1,600,0.5 \mathrm{~s}$ ) with the three largest multiply charged ions (counts $>25$ ) in the survey scan sequentially subjected to MS/MS analysis. MS/MS spectra were accumulated for $2 \mathrm{~s}$ ( $m / z$ 100-1,600). The data was processed using the database search program, Mascot (Matrix Science Ltd, London UK). Peak lists were searched against Other green plants in the SwissProt database [35]. High scores in the database search indicated a likely match, confirmed or qualified by operator inspection. Search results were generated with a 
significance threshold of $p<0.01$. An overview of the entire sample preparation method can be seen in Fig. 1.

\section{Intracellular copper analysis}

Cells previously exposed for $72 \mathrm{~h}$ to copper at the relevant $\mathrm{IC}_{50}$ copper concentration were concentrated, rinsed with filtered seawater then washed for 20 minutes with an EDTA buffer (0.01 M EDTA, $0.1 \mathrm{M} \mathrm{KH}_{2} \mathrm{PO}_{4} / \mathrm{K}_{2} \mathrm{HPO}_{4}$ buffer to $\mathrm{pH} 6.0$, salinity adjusted to $2.5 \%$ ). The cell suspension was centrifuged and the supernatant discarded. The remaining pellet was digested overnight in $1 \mathrm{ml}$ of an 80:20 mixture of concentrated $\mathrm{HNO}_{3}$ (TracePur, Merck) and $\mathrm{H}_{2} \mathrm{O}_{2}$ (Suprapur, Merck) at $21 \pm 1{ }^{\circ} \mathrm{C}$. Digests were then diluted to $5 \% \mathrm{HNO}_{3}$ for copper analysis. Digestions of certified reference material DOLT-3 (dogfish liver) were also determined to ensure complete digestion. The concentrations of copper added to natural seawaters (acidified to $0.8 \% \mathrm{HNO}_{3}$ (TracePur, Merck)) and within cells (intracellular copper, acidified to $5 \% \mathrm{HNO}_{3}$ ) were measured by inductively coupled plasma-atomic emission spectroscopy (ICP-AES, Agilent Varian 730-ES). Copper concentrations were calculated from a matrix-matched calibration curve (clean seawater or ultra-pure water, acidified with $0.8 \%$ or $5 \% \mathrm{HNO}_{3}$, respectively) using serial dilution of a mixed metal standard (QCD Analysts, Eaglewood, FL, USA). A drift standard was incorporated into the analysis procedure. The detection limit for copper was typically $\leq 2 \mu \mathrm{g} \mathrm{Cu} / 1$.

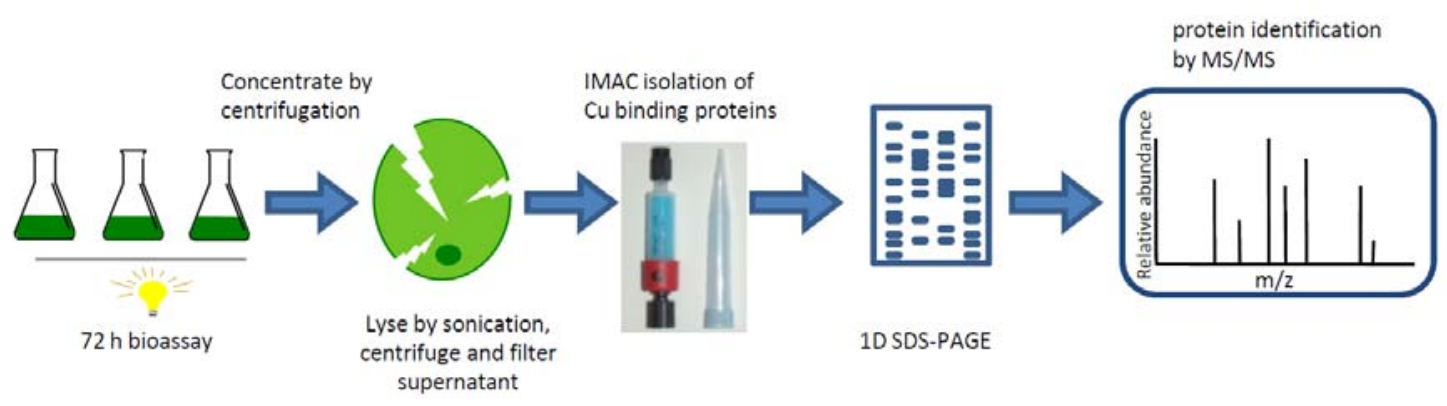

Fig. 1 Diagram representing the sample preparation steps from algal growth and copper exposure through to mass spectrometry (MS) analysis 


\section{Results and Discussion:}

To our knowledge IMAC has not previously been used to examine copper-binding proteins in marine microalgae. Thus the technique to extract and isolate the proteins required considerable optimisation, as described in the Experimental methods section. Sonication conditions were optimised and effectively ruptured $>80 \%$ of cells from $D$. tertiolecta, C. closterium and P. tricornutum and about $54 \%$ of those from Tetraselmis sp..

\section{Intracellular copper concentrations}

Intracellular copper concentrations were not proportional to exposure concentration nor to the sensitivity of the species (Table 1), which was similar to the findings of Levy et al. [1]. For example $D$. tertiolecta was exposed to nine times more copper than Tetraselmis sp. but internalised three times less copper than Tetraselmis sp. It should be noted that in the copper internalisation experiment Tetraselmis sp. exhibited less growth inhibition than expected based on the copper exposure concentration (Table 1); however this was not the case in the IMAC protein experiments.

Table 1 Exposure concentrations, intracellular copper and growth inhibition results from the intracellular copper experiment $(n=3)$

\begin{tabular}{lllll}
\hline Copper concentrations & D. tertiolecta & Tetraselmis sp. & P. tricornutum & C. closterium \\
\hline $\begin{array}{l}\text { Av. exposure concentration } \\
{[95 \% \mathrm{CI}](\mu \mathrm{g} \mathrm{Cu} / \mathrm{l})}\end{array}$ & $350[330-370]$ & $38[36-40]$ & $6[3-9]$ & $15[12-18]$ \\
$\begin{array}{l}\text { Intracellular copper after } \\
72 \mathrm{~h} \mathrm{IC}\end{array}$ & & & \\
$\mathrm{SE}\left(\mathrm{x} 10^{-16} \mathrm{~g} \mathrm{Cu} / \mathrm{cell}\right)$ & & $1,200 \pm 200$ & $120 \pm 50$ & $570 \pm 90$ \\
$\%$ growth inhibition after & $49 \pm 4$ & $11 \pm 4$ & $46 \pm 7$ & $79 \pm 4$ \\
$72 \mathrm{~h}$ copper exposure $\pm \mathrm{SE}$ & & & \\
\hline
\end{tabular}

$C I=$ Confidence interval $\left(\mathrm{s}_{\mathrm{x}}\right.$ was calculated from linear regression and used in the formula $\left(\mathrm{t}_{\mathrm{n}-2} \mathrm{~S}_{\mathrm{x}}\right)$

$S E=$ Standard Error $($ Standard deviation $/ \sqrt{ } \mathrm{N})$ where $\mathrm{N}$ is the number of replicates.

\section{Analysis of isolated proteins}

For each algal species, proteins in control and copper exposed cells were compared. Each species showed a different pattern of protein bands recovered by IMAC. The results from these comparisons are summarised in Table 2. The comparisons were made for individual bands and results pooled into molecular mass ranges. Individual band intensities were compared on SDS-PAGE gels between copper-exposed and unexposed control cells and bands were chosen for further analysis based on the copper exposed protein exhibiting $>75 \%$ changes relative to controls in replicate gels and replicate samples. In C. closterium, some proteins were barely detectable following copper exposure ( $75 \mathrm{kDa}$, Fig. 2$)$, but a new band 
was also detected at $\sim 50 \mathrm{kDa}$ that was absent in control cells (Fig. 2). For Tetraselmis sp., one band in the 40-60 kDa range was also identified as substantially less intense for coppertreated versus control cells (Fig. 2). Differences in protein recovery were also observed between control and copper-treated $D$. tertiolecta and $P$. tricornutum. In copper exposed $D$. tertiolecta, there was an increase in the intensity of protein bands in both the 60-75 and 75-85 $\mathrm{kDa}$ ranges, and for $P$. tricornutum, there was an increase in the $60-75 \mathrm{kDa}$ range in copperexposed cells (Table 2). However, the protein profiles produced were complex and would require further separation and/or sample clean up before individual proteins could be separated sufficiently to enable identification, thus the $D$. tertiolecta and P. tricornutum species were not investigated futher here.

Table 2 Copper induced changes in the levels of IMAC recoverable proteins in four marine microalgae, relative to unexposed controls

\begin{tabular}{lllll}
\hline Region $(\mathrm{kDa})$ & D. tertiolecta & Tetraselmis sp. & P. tricornutum & C. closterium \\
\hline $0-40$ & $\sim$ & $\sim$ & $\sim$ & $51-75 \%$ decrease \\
$40-60$ & $\sim$ & $76-100 \%$ decrease & $\sim$ & $>100 \%$ increase \\
$60-75$ & $>100 \%$ increase & $\sim$ & $>100 \%$ increase & $>100 \%$ decrease \\
$75-85$ & $>100 \%$ increase & $\sim$ & $\sim$ & $\sim$ \\
$85-100$ & $\sim$ & $\sim$ & $\sim$ & $\sim$ \\
$100-200$ & $\sim$ & $\sim$ & $\sim$ & $\sim$
\end{tabular}

$\sim$ Differences in band intensity were very small in these regions 


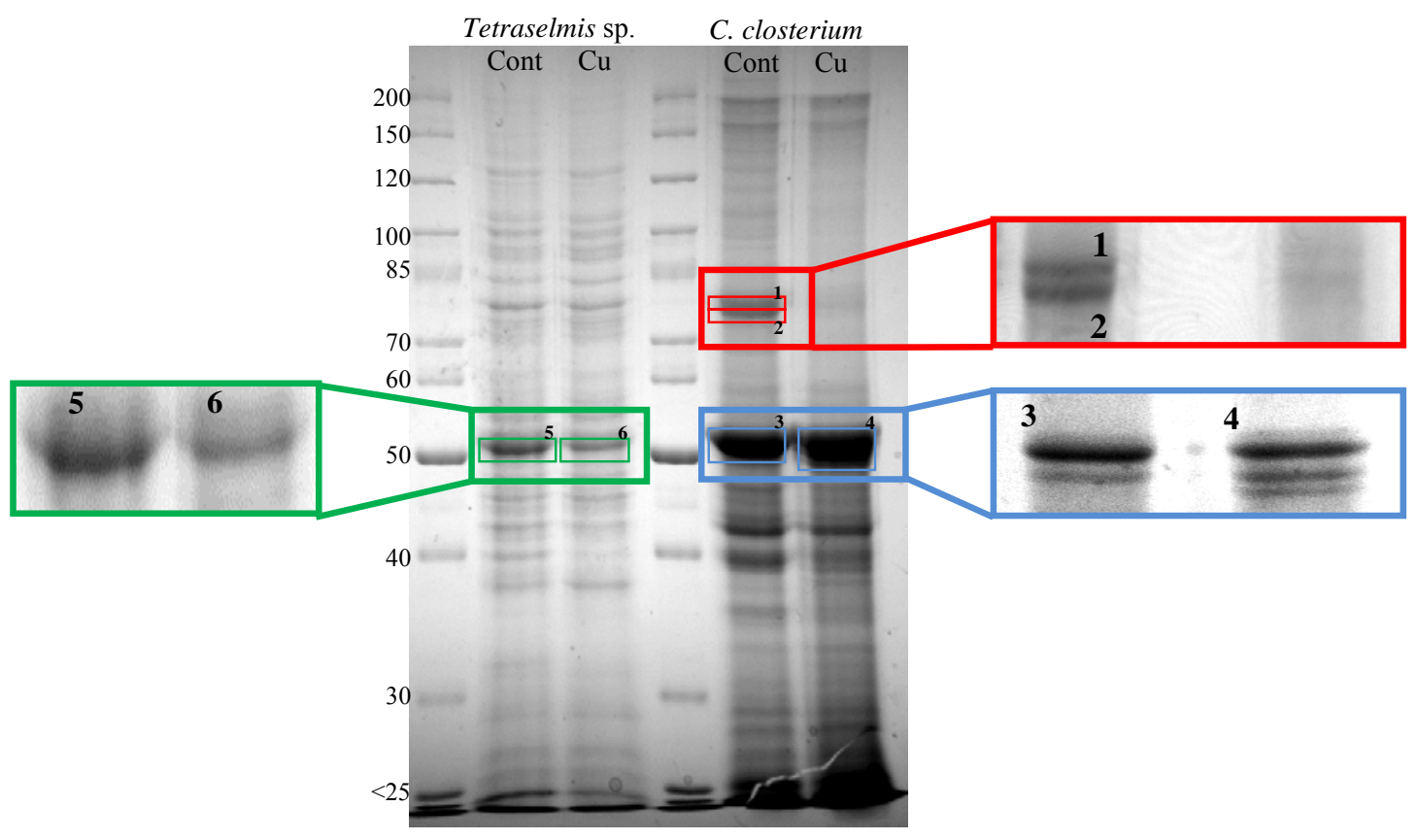

Fig. 2 SDS-PAGE showing copper-binding protein profiles of control and 72-h copper exposed cells from Tetraselmis sp. and Ceratoneis closterium. Numbered bands represent band clusters chosen for further analysis as the copper exposed bands exhibited changes $>75 \%$ relative to controls in replicate gels and replicate samples. Inset shows expanded region of band clusters noting that band cluster 3 contained 2 bands, and band cluster 4 contained 3 bands. Expanded region showing band cluster 3 and 4 comes from a separate gel with minimal protein loaded to enable resolution of these bands, there was insufficient protein for further analysis

In this study, the protein profiles produced are operationally defined, as IMAC does not capture all metal-binding proteins. Experiments were performed at the $\mathrm{IC}_{50}$ concentrations of each algal species, as we have assumed that cells can cope at this level of copper exposure demonstrated by growth and division still occuring at 50\% the rate of control populations. Therefore, we assume that detoxification mechanisms are not completely overwhelmed at this exposure level, and any proteins produced in response to the copper would be in excess of intracellular copper. However in the event that a protein had all of its binding sites saturated with metals prior to the IMAC separation, it may not be retained by the column. 


\section{Identification of copper-affected proteins}

Mass spectrometry results were analysed and the "top" matches compiled along with relevant information regarding the quality of the matches (Table 3$)$. Protein score is $-\log (p)$ where $p$ is the probability that the observed match is a random event. Protein scores $>28(p<0.01)$ were considered significant. Alignments of the sequences for all species matched were performed as well as for the top three species matches and amino acid sequence homology was calculated. All results discussed in the following (except where noted) can be found in Table 3.

For C. closterium two bands at $\sim 75 \mathrm{kDa}$ (Fig. 2, band 1 and 2) were evident in proteins purified from control cell lysates; however, these bands were barely detectable in the corresponding protein fraction of copper exposed cell lysates. There are several possible explanations for this: the expression of the proteins may be repressed, they may have become bound to copper within the cell rendering the proteins insoluble, or binding to copper may have altered their conformation such that they are no longer able to bind to the IMAC column. In any case, the availability of these proteins for cellular activity is likely to be compromised.

As discussed above, protein band 1 examined (Table 3 and Fig. 2) from the control $C$. closterium was not able to be identified from the database, with all possible matches outside the molecular weight range of the excised band and with low protein scores. This may be because it is a newly identified protein; however, it is also possible that this band contained a mixture of proteins none of which were present in sufficient amounts to enable a match. The second C. closterium protein band at $\sim 75 \mathrm{kDa}$ (Table 3, band 2), which was less abundant in lysates from $\mathrm{Cu}$-treated cells, showed matches for some chaperone and heat-shock proteins (all from the HSP70 family). Heat shock proteins (HSP) and chaperones are involved in the unfolding and refolding of proteins [36]. The absence, undersupply or non-functionality of this class of proteins is a possible cause of toxicity in cells as they are involved in maintaining cell homeostasis as part of the cell's defence mechanism against cellular stress [36]. HSPs respond to a variety of cellular stresses other than temperature, including metal exposure, oxygen radicals and peroxides [37]. The HSP70 family proteins identified in $C$. closterium are highly conserved and demonstrate (among eukaryotes) around a $70 \%$ amino acid identity [38]. Although only $6 \%$ of the amino acid sequence was matched in the search, the high level of conservation implies that the protein belongs to the HSP70 family.

Another change identified by analyses of lysates prepared from C. closterium cells was the appearance of an additional band at $\sim 50 \mathrm{kDa}$ in the copper exposed cells that was not present in control C. closterium cells (Fig. 2, band cluster 4). Resolution between bands was low when $\sim 50 \mu \mathrm{g}$ of protein was loaded onto the gel. Band clusters 3 and 4 (Table 3 and Fig. 2) could only be resolved when significantly less protein $(\sim 5-10 \mu \mathrm{g})$ was loaded onto the electrophoresis gel; however, this did not permit excision of sufficient protein from the band of interest for further analysis (Fig. 2, inset of band cluster 3 and 4). Thus the band clusters were excised as a single sample and analysed. 
Table 3 Protein matches for selected proteins (chosen for further analysis as the copper exposed protein exhibited changes $>75 \%$ relative to controls in replicate gels and replicate samples) bound to a $\mathrm{Cu}$-IMAC column (labelled band clusters 1-6 from Fig. 2) from lysates prepared from two marine microalgal species Ceratoneis closterium and Tetraselmis sp.

\begin{tabular}{|c|c|c|c|c|c|c|c|c|c|}
\hline $\begin{array}{l}\text { Sample/ } \\
\text { Species }\end{array}$ & Protein & $\begin{array}{c}\text { \# species } \\
\text { matching } \\
\text { protein }\end{array}$ & $\begin{array}{l}\text { Homology } \\
\text { (\%) }\end{array}$ & Top species matches for the protein ( $\max 3)$ & $\begin{array}{c}\text { Molecular } \\
\text { weight (Da) }\end{array}$ & $\begin{array}{l}\text { Homology } \\
\text { top } 3 \\
\text { species (\%) }\end{array}$ & $\begin{array}{l}\text { \# unique } \\
\text { matches }\end{array}$ & $\begin{array}{c}\text { Sequence } \\
\text { coverage } \\
(\%)\end{array}$ & $\begin{array}{c}\text { Protein } \\
\text { score }\end{array}$ \\
\hline $\begin{array}{c}\text { Band cluster 1 } \\
\text { Ceratoneis } \\
\text { closterium control }\end{array}$ & $\begin{array}{l}\text { Ribulose bisphosphate carboxylase } \\
\text { large chain }\end{array}$ & 1 & - & Cylindrotheca sp. & 54,001 & - & 2 & 6 & 104 \\
\hline (Decrease in & uncharacterized ycf88 & 1 & - & Odontella sinensis & 17,379 & - & 1 & 19 & 48 \\
\hline $\begin{array}{l}\text { expression after } \\
\text { copper exposure) }\end{array}$ & $\begin{array}{l}\text { ATP synthase subunit delta, } \\
\text { chloroplastic }\end{array}$ & 1 & - & Odontella sinensis & 21,117 & - & 1 & 7 & 30 \\
\hline $\begin{array}{c}\text { Band cluster } 2 \\
\text { Ceratoneis } \\
\text { closterium control }\end{array}$ & $\begin{array}{c}\text { Ribulose bisphosphate carboxylase } \\
\text { large chain }\end{array}$ & 1 & - & Cylindrotheca sp. & 54,001 & - & 2 & 4 & 131 \\
\hline $\begin{array}{l}\text { (Decrease in } \\
\text { expression after }\end{array}$ & Chaperone protein dnaK & 2 & 74 & $\begin{array}{l}\text { Odontella sinensis } \\
\text { Thalassiosira pseudonana }\end{array}$ & $\begin{array}{l}67,128 \\
65,298\end{array}$ & 74 & $\begin{array}{l}2 \\
2\end{array}$ & $\begin{array}{l}6 \\
6\end{array}$ & $\begin{array}{l}112 \\
104\end{array}$ \\
\hline copper exposure) & Heat shock 70-related protein & 2 & 60 & $\begin{array}{l}\text { Leishmania major (fragment) } \\
\text { Pyrenomonas salina }\end{array}$ & $\begin{array}{l}24,796 \\
72,035\end{array}$ & 60 & $\begin{array}{l}1 \\
1\end{array}$ & $\begin{array}{l}7 \\
2\end{array}$ & $\begin{array}{l}73 \\
73\end{array}$ \\
\hline $\begin{array}{c}\text { Band cluster } 3 \\
\text { Ceratoneis } \\
\text { closterium control }\end{array}$ & $\begin{array}{c}\text { Ribulose bisphosphate carboxylase } \\
\text { large chain }\end{array}$ & 5 & 68 & $\begin{array}{l}\text { Cylindrotheca sp. } \\
\text { Thalassiosira pseudonana } \\
\text { Cyanidioschyzon merolae }\end{array}$ & $\begin{array}{l}54,001 \\
54,289 \\
54,099\end{array}$ & 82 & $\begin{array}{c}12 \\
9 \\
8\end{array}$ & $\begin{array}{l}27 \\
17 \\
16\end{array}$ & $\begin{array}{l}749 \\
404 \\
332\end{array}$ \\
\hline $\begin{array}{l}\text { (Two bands present in } \\
\text { control cells) }\end{array}$ & $\begin{array}{l}\text { ATP synthase subunit beta, } \\
\text { chloroplastic }\end{array}$ & 2 & 93 & $\begin{array}{l}\text { Odontella sinensis } \\
\text { Thalassiosira pseudonana }\end{array}$ & $\begin{array}{l}51,477 \\
51,111\end{array}$ & 93 & $\begin{array}{l}2 \\
2\end{array}$ & $\begin{array}{l}6 \\
6\end{array}$ & $\begin{array}{l}134 \\
134\end{array}$ \\
\hline & $\begin{array}{l}\text { Glyceraldehyde-3-phosphate } \\
\text { dehydrogenase, chloroplastic }\end{array}$ & 1 & - & Chondrus crispus & 44,430 & - & 1 & 3 & 28 \\
\hline $\begin{array}{l}\text { Band cluster } 4 \\
\text { Ceratoneis } \\
\text { closterium copper }\end{array}$ & $\begin{array}{c}\text { Ribulose bisphosphate carboxylase } \\
\text { large chain }\end{array}$ & 8 & 42 & $\begin{array}{l}\text { Cylindrotheca sp. } \\
\text { Thalassiosira pseudonana } \\
\text { Cyanidioschyzon merolae }\end{array}$ & $\begin{array}{l}54,001 \\
54,289 \\
54,099\end{array}$ & 82 & $\begin{array}{c}12 \\
9 \\
7\end{array}$ & $\begin{array}{l}26 \\
20 \\
14\end{array}$ & $\begin{array}{c}1312 \\
488 \\
427\end{array}$ \\
\hline \multirow[t]{2}{*}{$\begin{array}{l}\text { (Three bands present } \\
\text { in copper exposed } \\
\text { cells) }\end{array}$} & $\begin{array}{l}\text { ATP synthase subunit beta, } \\
\text { chloroplastic }\end{array}$ & 2 & 93 & $\begin{array}{l}\text { Odontella sinensis } \\
\text { Thalassiosira pseudonana }\end{array}$ & $\begin{array}{l}51,477 \\
51,111\end{array}$ & 93 & $\begin{array}{l}1 \\
1\end{array}$ & $\begin{array}{l}3 \\
3\end{array}$ & $\begin{array}{l}101 \\
101\end{array}$ \\
\hline & $\begin{array}{l}\text { ATP synthase subunit alpha, } \\
\text { mitochondrial }\end{array}$ & 1 & - & Dictyostelium citrinum & 57,224 & - & 1 & 3 & 59 \\
\hline
\end{tabular}




\begin{tabular}{|c|c|c|c|c|c|c|c|c|c|}
\hline $\begin{array}{c}\text { Sample/ } \\
\text { Species }\end{array}$ & Protein & $\begin{array}{l}\text { \# species } \\
\text { matching } \\
\text { protein }\end{array}$ & $\begin{array}{c}\text { Homology } \\
(\%)\end{array}$ & Top species matches for the protein $(\max 3)$ & $\begin{array}{c}\text { Molecular } \\
\text { weight }\end{array}$ & $\begin{array}{l}\text { Homology } \\
\text { top } 3 \\
\text { species (\%) }\end{array}$ & $\begin{array}{l}\# \text { unique } \\
\text { matches }\end{array}$ & $\begin{array}{l}\text { Sequence } \\
\text { coverage } \\
\text { (\%) }\end{array}$ & $\begin{array}{c}\text { Protein } \\
\text { score }\end{array}$ \\
\hline \multirow{3}{*}{$\begin{array}{l}\text { Band cluster } 5 \\
\text { Tetraselmis sp. } \\
\text { control }\end{array}$} & Ribulose bisphosphate carboxylase & 9 & 43 & Euglena viridis (fragment) & 48,328 & 94 & 5 & 13 & 315 \\
\hline & large chain & & & Euglena anabaena (fragment) & 48,256 & & 6 & 15 & 209 \\
\hline & & & & Euglena geniculata (fragment) & 48,193 & & 6 & 15 & 209 \\
\hline \multirow{9}{*}{$\begin{array}{l}\text { Decrease in } \\
\text { expression after } \\
\text { copper exposure }\end{array}$} & Tubulin beta chain & 3 & 87 & Cyanophora paradoxa (beta-1) & 49,792 & 87 & 3 & 8 & 165 \\
\hline & & & & Ectocarpus variabilis (beta-5) & 49,973 & & 1 & 4 & 117 \\
\hline & & & & Ectocarpus variabilis (beta-6) & 50,114 & & 1 & 4 & 117 \\
\hline & Tubulin alpha chain & 4 & 72 & Pelvetia fastigiata (alpha-1 chain) & 49,905 & 74 & 1 & 4 & 111 \\
\hline & & & & Pelvetia fastigiata (alpha-2 chain) & 49,948 & & 1 & 4 & 111 \\
\hline & & & & Guillardia theta (alpha chain, nucleomorph) & 49,771 & & 1 & 4 & 90 \\
\hline & ATP synthase subunit beta, & 17 & 60 & Cyanidium caldarium & 53,244 & 72 & 1 & 3 & 52 \\
\hline & chloroplastic & & & Cyanidioschyzon merolae & 50,382 & & 1 & 3 & 52 \\
\hline & & & & Dictyota dichotoma & 52,171 & & 1 & 3 & 52 \\
\hline \multirow{3}{*}{$\begin{array}{l}\text { Band cluster } 6 \\
\text { Tetraselmis sp. } \\
\text { copper }\end{array}$} & ATP synthase subunit beta, & 3 & 88 & Dictyota dichotoma & 52,171 & 88 & 7 & 19 & 262 \\
\hline & chloroplastic & & & Fucus vesiculosus & 51,541 & & 7 & 19 & 262 \\
\hline & & & & Pylaiella littoralis & 51,993 & & 7 & 19 & 262 \\
\hline \multirow{11}{*}{$\begin{array}{l}\text { Decrease in } \\
\text { expression after } \\
\text { copper exposure }\end{array}$} & Tubulin beta chain & 4 & 83 & Cyanophora paradoxa (beta-1) & 49,792 & 83 & 5 & 12 & 279 \\
\hline & & & & Oomycete-like sp. strain MacKay2000 (beta-4) & 50,334 & & 4 & 9 & 191 \\
\hline & & & & Ectocarpus variabilis (beta-5) & 49,973 & & 1 & 4 & 99 \\
\hline & Tubulin alpha chain & 5 & 82 & Pelvetia fastigiata (alpha-2) & 49,948 & 88 & 4 & 15 & 232 \\
\hline & & & & Naegleria gruberi (alpha $1 / 2 / 3$ ) & 49,810 & & 3 & 10 & 143 \\
\hline & & & & Naegleria gruberi (alpha-13) & 49,782 & & 3 & 10 & 143 \\
\hline & Ribulose bisphosphate carboxylase & 8 & 44 & Euglena viridis (fragment) & 48,328 & 94 & 4 & 7 & 205 \\
\hline & large chain & & & Euglena anabaena (fragment) & 48,256 & & 5 & 11 & 187 \\
\hline & & & & Euglena geniculata (fragment) & 48,193 & & 5 & 11 & 187 \\
\hline & V-type proton ATPase subunit B & 1 & - & Cyanidium caldarium & 56,398 & - & 1 & 3 & 59 \\
\hline & $\begin{array}{c}\text { Mitochondrial import inner } \\
\text { membrane translocase subunit } \\
\text { TIM50 }\end{array}$ & 1 & - & Phytophtora infestans & 45,237 & - & 1 & 2 & 29 \\
\hline
\end{tabular}

Protein score is $-\log (p)$ where $p$ is the probability that the observed match is a random event. Protein scores $\geq 28(p<0.01)$ were considered significant 
Several proteins were identified in band clusters 3 and 4 from C. closterium extracts at $\sim 50$ $\mathrm{kDa}$ (control and copper exposed, Fig. 2, band 3 and 4). The strongest match for the most abundant protein at this size was Ribulose bisphosphate carboxylase large chain (Rubisco), which is one of the most abundant proteins in the world [39], and consists of a large chain component (typically $50-55 \mathrm{kDa}$ ) and a small chain component (typically $\sim 15 \mathrm{kDa}$ ) [40]. Rubisco is involved in carbon fixation and therefore is expected to be found in all algal cells. While this may be the higher molecular weight protein in band clusters 3 and 4, it is unlikely to be lower molecular weight protein band unique to copper-exposed C. closterium (Fig. 2 band 4).

Rubisco was also found in both the control and copper exposed Tetraselmis sp. mass spectrometry analyses of proteins extracted from the gels within bands 5 and 6 (Table 3 and Fig. 2, band 5 and 6), with less protein detected in the copper exposed cells (band 6). For C. closterium protein matches were to two other diatoms Cylindrotheca and Thalassiosira and for Tetraselmis sp. matches were to Euglena (unicellular flagellate protists); this likely corresponds to differences between diatoms and green algae. Ceratoneis closterium has also been known by the names Cylindrotheca closterium and Nitzschia closterium [41]. Therefore, the Cylindrotheca sp. protein matches from the Mascot databank could be from a closelyrelated species or indeed from the same species as that used in this study. Rubisco has been shown to decrease in both amount and enzymatic activity following copper exposure in rice plants (Oryza sativa L.) [42,43] and barley plants [44]. In O. sativa L. degradation products of the large chain subunit were observed following exposure to copper [42].

Bands 5 and 6 (Fig. 2) from Tetraselmis sp. had several other protein matches in addition to Rubisco. These included ATP (adenosine tri-phosphate) synthase (subunit $\beta$ ) and tubulin ( $\alpha$ and $\beta$ ). Although the same proteins were identified in both the copper-exposed and control treatments (Table 3, bands 5 and 6), overall there was a decrease in band 6 intensity for the copper-exposed Tetraselmis sp. (Fig. 2, band 6).

$\alpha$ and $\beta$ tubulins form a heterodimeric complex known as microtubules, these are important structural building blocks for structures such as flagella [45]. $\alpha$ and $\beta$ tubulins are different in structure, however their individual structures are highly conserved amongst a variety of families [46]. When comparing the whole superfamily of tubulins (including $\alpha, \beta, \gamma, \delta, \varepsilon, \zeta$ and $\eta$ ) only the guanidine di- or tri-phosphate (GDP/GTP)-binding site (and several other single amino acids) are conserved. However, whilst their structures are different, tubulins have a related function [46], as an important component in spindle formation during cell division. Spindle formation and dissolution depend on the ratio between sulfhydryl groups and disulfide bonds [47]. Although the data from this experiment is unable to conclusively show whether copper has had an effect on tubulin levels within the cell, copper is redox active and would be able to oxidise sulfhydryl groups e.g. in glutathione and in tubulins, leading to impacts on microtubule assembly and subsequent inhibition of cell division [47]. ATP synthase (subunit $\beta$ ) was matched in both control and copper exposed cells from C. closterium (Fig. 2, band 3 and 4) and Tetraselmis sp. (Table 3, band 5 and 6). In Tetraselmis sp., a decrease in the overall intensity of this band was observed after copper exposure and may be a result of a decrease in the levels of one or several of the identified 
proteins from this band (Fig. 2, band 6). The whole ATP synthase complex catalyses the formation of ATP, the "energy currency" of the cell $[48,49]$. The structure of the $\beta$ subunit of ATP synthase is highly conserved. In a study by Runswick and Walker [48] the alignment between the $\beta$ subunits of spinach chloroplasts, maize chloroplasts, bovine mitochondria and Escherichia coli had more than $50 \%$ identity over all four species, and this increased to between 64 and 88\% when comparing any two of the species. This is relatively high conservation considering the variety of species being examined. This shows that the matches for ATP synthase subunit $\beta$ are quite strong matches (Table 3, band 3, 4, 5 and 6) given the high level of homology within this particular protein's evolution. Previous publications on algae, tomato plants and rat hepatoma cells have shown metal (including copper) inhibition of ATP-synthesis [50-52]. ATP is essential for energy-requiring cellular processes, thus inhibition of ATP synthesis by copper can be one important mode of metal toxicity to algae.

The most copper tolerant species in this study (D. tertiolecta) showed fewer changes overall in the levels of copper binding proteins following copper exposure than the more sensitive species C. closterium. This supports the original hypothesis that proteins bound to the IMAC column from the tolerant species would be less affected. Tetraselmis sp. is also reasonably tolerant (with an $\mathrm{IC}_{50}$ value of approximately 2-3 times greater than C. closterium) and it too exhibited smaller changes than C. closterium. However, in contrast and contradiction to the hypothesis, $P$. tricornutum has smaller changes in the copper-binding proteins detected following copper exposure than $C$. closterium despite $P$. tricornutum being more copper sensitive than the latter. This may be due to the amount of intracellular copper content where $P$. tricornutum uptakes approximately five times less copper over $72 \mathrm{~h}$. Furthermore, the amount of copper internalised by the different algae differs from the order of their respective copper tolerances. When exposed to their respective $\mathrm{IC}_{50}$ copper concentration, Tetraselmis sp. internalises significantly more copper than C. closterium (Table 1; 1,200 \pm 200 and $570 \pm 90 \times 10^{-16} \mathrm{~g} \mathrm{Cu} /$ cell, respectively) however both internalised more than either of the other two species.

The IMAC/SDS-PAGE method used in this study has identified a number of protein bands that may be affected by cell exposure to copper. Some of the bands contained multiple proteins so we were unable to unequivocally state that specific protein(s) were affected by copper exposure. In this study, the protein bands (bound to and recovered from IMAC) that were affected when algae were exposed to copper included heat-shock proteins, tubulins ( $\alpha$ and $\beta$ ), Rubisco (large chain) and ATP synthase ( $\beta$ subunit). The observed changes in protein band intensity may reflect changes in protein expression, conformation, or metal complexation within the cell. Whilst the results from this study alone are not yet able to fully explain the differences in copper tolerance between these species, future work in our laboratory examining copper uptake, intracellular localisation and detoxification processes (such as phytochelatins) in marine algae may provide further insights into the mode of action of copper and will be the focus of future studies. 


\section{Conclusions}

This study used $\mathrm{Cu}$-IMAC and SDS-PAGE to identify changes in the recovery of copperbinding proteins from copper-exposed and untreated control cells from four species of marine microalgae. IMAC was successfully used to isolate copper binding proteins from complex marine microalgal lysates. A $72-\mathrm{h}$ exposure of cells to the $\mathrm{IC}_{50}$ copper concentration was found to alter the levels of copper-binding proteins recovered from lysates of the four species. In some cases copper exposure led to a decrease in the amount of detectable protein, and in one case, the appearance of an additional protein not previously detected. For P. tricornutum and D. tertiolecta, although differences in proteins were detected between copper exposed and unexposed cells, the complexity of the copper-binding protein fraction meant that 1-D SDS-PAGE was unable to sufficiently resolve the protein bands to permit further investigation. In future work this could be remedied by employing 2-D electrophoresis (separating by both isoelectric point and size) to better resolve the proteins prior to subsequent analysis $[53,26]$. The proteins thus identified are likely to play roles in copper homeostasis and toxicity in marine microalgae.

\section{Acknowledgments}

The authors would like to thank Rebecca Ronchin for assistance in optimising the sonication parameters for cell lysis. C. Smith was awarded an Australian Postgraduate Award scholarship for the duration of this work. The protein identification work was undertaken at APAF, the infrastructure provided by the Australian Government through the National Collaborative Research Infrastructure Strategy (NCRIS).

\section{References:}

1. Levy JL, Angel BM, Stauber JL, Poon WL, Simpson SL, Cheng SH, Jolley DF (2008) Uptake and comparison of copper by three marine microalgae: Comparison of copper-sensitive and coppertolerant species. Aquat Toxicol 89:82-93

2. Stauber JL, Davies CM (2000) Use and limitations of microbial bioassays for assessing copper availability in the aquatic environment. Environ Rev 8:255-301

3. Jonsson CM, Aoyama H (2010) Effect of copper on the activation of the acid phosphatase from the green algae Pseudokirchneriella subcapitata. BioMetals 23 (1):93-98

4. Fernandes JC, Henriques FS (1991) Biochemical, physiological, and structural effects of excess copper in plants. Bot Rev 57 (3):246-273

5. Levy JL, Stauber JL, Jolley DF (2007) Sensitivity of marine microalgae to copper: The effect of biotic factors on copper adsorption and toxicity. Sci Total Environ 387:141-154

6. Pagenkopf GK (1983) Gill surface interaction model for trace metal toxicity to fishes: role of complexation, $\mathrm{pH}$ and water hardness. Environ Sci Technol 17:342-347

7. Morel FMM (1983). In: Principles of Aquatic Chemistry. Wiley-Interscience, New York, pp 301-308

8. Brown PL, Markich SJ (2000) Evaluation of the free ion activity model of metal-organism interaction: extension of the conceptual model. Aquat Toxicol 51 (2):177-194 
9. Di Toro DM, Allen HE, Bergman HL, Meyer JS, Paquin PR, Santore RC (2001) A biotic ligand model of the acute toxicity of metals (I). Environ Toxicol Chem 20:2383-2396

10. Santore RC, Di Toro DM, Paquin PR, Allen HE, Meyer JS (2001) A biotic ligand model of the acute toxicity of metals (II) Application to acute copper toxicity in freshwater fish and daphnia. Environ Toxicol Chem 20:2397-2402

11. Merchant SS, Allen MD, Kropat J, Moseley JL, Long JC, Tottey S, Terauchi AM (2006) Between a rock and a hard place: Trace element nutrition in Chlamydomonas. Biochim Biophys Acta-Mol Cell Res 1763 (7):578-594

12. Wolfe-Simon F, Grzebyk D, Schofield O (2005) The role and evolution of superoxide dismutases in algae. Journal of Phycology 41:453-465

13. Yadav SK (2010) Heavy metal toxicity in plants: An overview on the role of glutathione and phytochelatins in heavy metal stress tolerance of plants. S Afr J Bot 76:167-179

14. Ahner BA, Wei L, Oleson JR, Ogura N (2002) Glutathione and other low molecular weight thiols in marine phytoplankton under metal stress. Mar Ecol Prog Ser 232:93-103

15. Lavoie M, Faucheur S, Fortin C, Campbell PGC (2009) Cadmium detoxification strategies in two phytoplankton species: Metal binding by newly synthesized thiolated peptides and metal sequestration in granules. Aquat Toxicol 92:65-75

16. Porath J, Carlsson JAN, Olsson I, Belfrage G (1975) Metal chelate affinity chromatography, a new approach to protein fractionation. Nature 258 (5536):598-599

17. Hage DS, Anguizola JA, Bi C, Li R, Matsuda R, Papastavros E, Pfaunmiller E, Vargas J, Zheng X (2012) Pharmaceutical and biomedical applications of affinity chromatography: Recent trends and developments. J Pharm Biomed Anal 69:93-105

18. Pearson RG (1968) Hard and soft acids and bases HSAB, part I fundamental principles. J Chem Educ 45 (9):581-587

19. Housecroft CE, Constable EC (2010) Chemistry 4th Edition. Pearson Education Ltd, England

20. Katz AK, Shimoni-Livny L, Navon O, Navon N, Bock CW, Glusker JP (2003) Copper-binding motifs: Structural and Theoretical Aspects. Helv Chim Acta 86:1320-1338

21. Gaberc-Porekar V, Menart V (2001) Perspectives of immobilized-metal affinity chromatography. J Biochem Bioph Methods 49 (1-3):335-360

22. Hage DS (ed) (2006) Handbook of Affinity Chromatography, vol 92. Taylor \& Francis, Boca Raton, Florida

23. Gordon AS (1992) Isolation of compounds with affinity for copper from seawater using immobilized copper-ion affinity-chromatography. Mar Chem 38 (1-2):1-12

24. Ross ARS, Ikonomou MG, Orians KJ (2003) Characterization of copper-complexing ligands in seawater using immobilized copper(II)-ion affinity chromatography and electrospray ionization mass spectrometry. Mar Chem 83 (1-2):47-58

25. Gordon AS, Donat JR, Kango RA, Dyer BJ, Stuart LM (2000) Dissolved copper-complexing ligands in cultures of marine bacteria and estuarine water. Mar Chem 70 (1-3):149-160

26. Smith SD, She Y-M, Roberts EA, Sarkar B (2004) Using immobilized metal affinity chromatography, two-dimensional electrophoresis and mass spectrometry to identify hepatocellular proteins with copper-binding ability. J Proteome Res 3:834-840

27. Mestek O, Polák J, Koplík R, Šantrůček J, Kodíček M (2008) Isolation of ligands of trace metals from plant samples by immobilized metal affinity chromatography. Anal Lett 41:1459-1467

28. Mestek O, Komínková J, Koplík R, Šantrůček J, Polák J (2010) Trace elements distribution and species fractionation in the wheat (Triticum aestivum) plant. Chem Speciation Bioavailability 22 (1):61-70

29. Barnett JP, Scanlan DJ, Blindauer CA (2012) Fractionation and identification of metalloproteins from a marine cyanobacterium. Anal Bioanal Chem 402 (3371-3377):3371-3377

30. Johnson HL, Stauber JL, Adams MS, Jolley DF (2007) Copper and zinc tolerance of two tropical microalgae after copper acclimation. Environ Toxicol 22 (3):234-244

31. Guillard RRL, Ryther JH (1962) Studies of marine planktonic diatoms. Can J Microbiol 8:229-239 
32. Franklin NM, Stauber JL, Adams MS (2005) Improved methods of conducting microalgal bioassays using flow cytometry. . In: G.K.Ostrander (ed) Techniques in Aquatic Toxicology. Taylor and Francis, Boca Raton, USA, pp 735-756

33. Graham JM, Rickwood D (1997) Subcellular fractionation: A practical approach. Oxford University Press,

34. Storrie B, Madden EA (1990) Isolation of sub-cellular organelles. Methods Enzymol 182:203-225

35. Bairoch A, Apweiler R (2000) The SWISS-PROT protein sequence database and its supplement TrEMBL in 2000. Nucleic Acids Res 28:45-48

36. Wang W, Vinocur B, Shoseyov O, Altman A (2004) Role of plant heat-shock proteins and molecular chaperones in the abiotic stress response. Trends Plant Sci 9 (5):244-252

37. De Maio A (1999) Heat shock proteins: Facts, thoughts and dreams. Shock 11 (1):1-12

38. Kiang J, Tsokos GC (1998) Heat shock protein 70 kDa: Molecular biology, biochemistry, and physiology. Pharmacol Ther 80 (2):183-201

39. Ellis RJ (1979) The most abundant protein in the world. Trends Biochem Sci 4 (11):241-244

40. Taylor TC, Backlund A, Bjorhall K, Spreitzer RJ, Andersson I (2001) First crystal structure of Rubisco from a green alga, Chlamydomonas reinhardtii. J Biol Chem 276 (51):48159-48164

41. Hallegraeff GM, Bolch CJS, Hill DRA, Jameson I, Leroi J-M, McMinn A, Murray S, De Salas MF, Saunders K (2010) Phytoplankton of temperate coastal waters. Algae of Australia. Australian Biological Resources Study/CSIRO publishing, Canberra

42. Hajduch M, Rakwal R, Agrawal GK, Yonekura M, Pretova A (2001) High-resolution twodimensional electrophoresis separation of proteins from metal-stressed rice (Oryza sativa L.) leaves: Drastic reductions/fragmentation of ribulose-1,5-bisphosphate carboxylase/oxygenase and induction of stress-related proteins. Electrophoresis 22 (2824-2831)

43. Lindon FC, Henriques FS (1991) Limiting step on photosynthesis of rice plants treated with varying copper levels. Journal of Plant Physiology 138 (115-118)

44. Demirevska-Kepova K, Simova-Stoilova L, Stoyanova Z, Hölzer R, Feller U (2004) Biochemical changes in barley plants after excessive supply of copper and manganese. Environ Exp Bot 52:253-266

45. Stephens RE (1978) Primary structural differences among tubulin subunits from flagella, cilia, and the cytoplasm. Biochemistry (Wash) 17 (14):2882-2891

46. Dutcher SK (2001) The tubulin fraternity: alpha to eta. Curr Opin Cell Biol 13:49-54

47. Önfelt A (1983) Spindle disturbances in mammalian cells. I. changes in the quantity of free sulfhydryl groups in relation to survival and c-mitosis in V79 Chinese hamster cells after treatment with colemid, diamide, carbaryl and methyl mercury. Chem Biol Interact 46:201-217

48. Runswick MJ, Walker JE (1983) The amino acid sequence of the $\beta$-subunit of ATP synthase from bovine heart mitochondria. J Biol Chem 258 (5):3081-3089

49. Walker JE, Saraste M, Runswick MJ, Gay NJ (1982) Distantly related sequences in the $\alpha$ - and $\beta$ subunits of ATP synthase, myosin, kinases and other ATP-requiring enzymes and a common nucleotide binding fold. EMBO (Eur Mol Biol Organ) J 1 (8):945-951

50. Cid A, Herrero C, Torres E, Abalde J (1995) Copper toxicity on the marine microalga Phaeodactylum tricornutum: effects on photosynthesis and related parameters. Aquat Toxicol 31:165-174

51. Steinebach OM, Wolterbeek HT (1994) Role of cytosolic copper, metallothionein and glutahtione in copper toxicity in rat hepatoma tissue culture cells. Toxicology 92:75-90

52. Rodríguez-Celma J, Rellán-Álvarez R, Abadía A, Abadía J, López-Millán A-F (2010) Changes induced by two levels of cadmium toxicity in the 2-DE protein profile of tomato roots. Journal of Proteomics 73:1694-1706

53. Ritter A, Ubertini M, Romac S, Gaillard F, Delage L, Mann A, Cock JM, Tonon T, Correa JA, Potin P (2010) Copper stress proteomics highlights local adaptation of two strains of the model brown alga Ectocarpus siliculosus. Proteomics 10:2074-2088 